\title{
Analysis of the Determinants of Banks Distress in Nigeria: An Autoregressive Distributed Lag Model Approach
}

\author{
Maryam A. Koko $\mathrm{PhD}^{1}$, Adamu Hassan ${ }^{2}$ \\ ${ }^{1}$ Department of Business Administration UsmanuDanfodiyo University, Sokoto \\ ${ }^{2}$ Department of Education Foundation Sokoto State University, Sokoto
}

\begin{abstract}
This study examines the causes of bank distress in Nigeria using annual data from 1986 to 2015. The study employed Autoregressive Distributed Lag Model developed by Pesaran et al (2001) as the technique of data analysis. The study reveals that exchange rate and non-performing loans have positive and statistically significant impact on bank distress, while inflation and interest rate have negative and statistically insignificant effect on bank distress. The study further found that liquidity ratio exerts positive and statistically insignificant influence on bank distress. In consistent with the findings, the study recommends the followings: firstly, there should be proactive measures by the banks such as loan surveillance and monitoring.The government should strengthen the mechanisms that will create favorable and sustainable macroeconomic stability in the economy; secondly, to guarantee effective control of non-performing loans, banks should ensure that loans to be given must satisfy the requirements of banking policy and finally, the Central Bank of Nigeria must ensure that deposit money banks are operating in line with the banking policy guide lines and any bank that violate or bridge the policy should be call to order or penalized.
\end{abstract}

Keywords: Financial Deepening, Non-performing loans, ARDL, Exchange Rate, Inflation.

\section{Introduction}

The role of banking sector to the development of any economy in both developed and developing countries including Nigeria cannot be overstated. Apart from meeting the financial needs to its customers, banks perform many functions, whichinclude: capital formation; financing trade, agriculture, industry, consumer activities and help in the implementation of monetary policy (Ademola, Olusegun and Kehinde, 2013).

In Nigeria, the banking operation started in the year 1829, when the African Banking Corporation (ABC) currently first Bank of Nigeria plc was established. In almost a century after the commencement of banking operations in the country, Nigeria experienced first bank distress in 1930, when the first indigenous bank, commercial and industrial banks ran into liquidation with total deposit liabilities of 23,000 British Pound Sterling (Abiola et al, year not given and Adeyemi, 2011). Consequently, the period of non-regulatory banking operation has came to an end in the year 1952, when the then colonial government promulgatedBanking Ordinance which took effect in 1954. Despite the introduction of the 1952 Banking Ordinance, series of bank crises continues to occur in Nigeria from 1952 to 1985 . This is because only 4 out of 25 indigenous banks established during this period survived (Adeyemi, 2011).

This undesirable crisis in the financial sector led to the establishment of Central Bank of Nigeria (CBN) and Nigeria Deposit Insurance Corporation (NDIC) in 1958 and 1988 respectively to control and regulate the business of banking industry. Between 1994 to 2003 Nigeria witness another series of banking crises in spite of promulgation of two regulating body namely; CBN and NDIC. Additionally, the 2004-2005 swept away 13 banks and the number of banks reduced to 25 from 89 by the year 2006. In 2009, 8 out of the 24 banks were distressed due to non-performing loans totaling $\$ 2.2$ trillion which is equivalent to $5.2 \%$ of Gross Domestic Product (GDP). In 2011 however, 6 other banks namely: AfriBank, Bank PHB, Spring Bank, Fin Bank, Intercontinental Bank and Oceanic Bank failed (Nnah; 2012, Adeyemi, 2011 and Elegbe, 2013). The events lead to the establishment of Asset Management Corporation of Nigerian AMCON under AMCON act 2010,the body acted as the buyer of banks of the Nigerian government by acquiring the non-performing loans.

The unwanted happening in the financial sector led to emergence of many empirical studies in the area with the view to investigates the main cause of the problem. For instance, World Bank (1989) as cited by Adeyemi (2011) and Elegbe (2013) noted that poor lending; mismatching of assets and liabilities; weak and inefficient internal control; inadequate policies; lack of standard practices and strategic planning as the major factor responsible for the persistent crisis in the Nigerian financial sector. Furthermore, Ogundina (1999) and Ogunbunka (2003) identified ownership structure, poor management and weak/ inefficient internal control system as sources of bank distress in Nigeria.

The main contribution of this paper is methodological and empirical. Methodologically, for been the first to apply most recently developed Autoregressive Distributed Lag Model (ARDL) in modeling the 
determinants of banks distress in Nigeria. Empirically, it adds new evidence and new dimension to the existing literature on the sources of banks distress in Nigeria.

However, the main aim of this paper is to investigate the causes of banks distress in Nigeria. To achieve the foregoing, the paper is divided into five sections including this introduction. Section two discusses conceptual issues and empirical evidences, section three presents methodology. Section four contains results discussion and analyses, while section five presents conclusion and recommendations.

\section{Conceptual Issues}

\section{Litrature Review}

The term bank distress has been defined as the bank with problems relating to illiquidity, poor earnings, and non-performing assets. The extreme case of distress is referred to as insolvency, which means that a bank's assets are less than its liabilities (CBN, 2011). Umoh (1999) noted that, a bank is distressed when it is technically insolvent meaning that bank's liabilities exceed its assets. Additionally, CBN and NDIC (1995) affirmed that a distressed financial institution is one with severe financial, operational and managerial weakness which have make it intricate for the institution to meet its obligations to its customers and owners when due.

In another development Alashi (2002) reported that bank is said to be in serious crisis when it shows most or all of the following: gross under capitalization in relation to the level and business character; high level of non-performing loans to total loans, illiquidity as reflected in a bank inability to meet customers demand for cash withdrawals; low earning causing in massive operational losses; and weak management as reflected by poor asset quality, inadequate internal controls, fraud among others.

However, there are number of reasons that have been contributed to the financial distress of deposit money bank in developed, emerging and developing economies.Hooks (1994) cited by Egbo (2012) stated that banks distress is attributable to deteriorating economic factors such as inflation rate, interest rate and exchange rate. Additionally, Sanusi (2010) reported that one of the sources of bank crisis in Nigeria is the instability in the macroeconomic variables.

Also bank distress is caused by capital inadequacy. According to Palubinskas and Stough (1999) in Egbo (2012) one of the measures used to forestall the severe crisis in the banking sector is to increase the ceiling of reserve capital held by the banks. This is also consistent with the view of Goodheart et al. (1989) cited by Egbo (2012) that adequate funds reduce risk-taking while insufficient capital drive banks to engage in actions towards survival at all costs. Furthermore, Musa et al. (2012) stated that increasing minimum capital requirement of the banks account for a short-term improvement in the liquidity position of the banks.

Another cause of banks distress is regulation of banks by the monetary authority. When government intervenes in forestalling the banks from distress, creditors and customers tend to depend on government to protect them. The regulation also is disincentive for other institutions, creditors and customers to effectively monitor their interest bank in an independent way (Egbo, 2012). Sanusi (2010) and Egbo (2012) maintained that bank failure is cause by ineffective regulatory system.

\section{Empirical Evidence}

Ohwofasa and Mayaku (2012) empirically examined the determinants of bank distress and effect on Nigerian economy. Annual series data were used for the period spanning from 1986 to 2010. The study used cointegration technique in testing the nexus among the variables. Bank crisis, money supply, inflation, exchange rate and corruption in the banking sector were used as the variables in the model. The results revealed that money supply and inflation have negative effect on bank crisis. Additionally, bank crisis and inflation have negative impact on economic growth. The study suggests strong management of money supply, inflation and corruption in the banking sector.

Elegbe (2013) investigated the relationship between bank failure and economic development in Nigeria. The study used time series data covering the period 2001 to 2010 and Ordinary Least Square (OLS) was used in the analysis. The variable of his choice were GDP, money supply, interest rate, industrial production index, cash reserve ratio and non-performing loans. The results showed that non-performing loans and interest rate have negative impact on economic development in Nigeria. The study recommended that, there should be need for harmonization of monetary and fiscal policies and that loan should be channel to the productive sector of the economy in order to generate futureeconomic development in Nigeria.

Musa et al., (2012) conducted a study on whether bank capitalization help in resuscitating liquidity or forestalling distress in the banking sector in Nigeria. The study used annual series data from 1997 to 2006 and Pearson Product Moment Correlation was used in the analysis. The study found that there is positive and statistically significant relationship between increase in minimum capital base of commercial banks and their liquidity. The study further discovered that minimum capital requirement has only short-term effect on banks liquidity position. They recommend the adoption of other approach to bank management such as corporate governance in order to protect long-term/ future occurrence of distress in the financial sector in Nigeria. 
Adeyemi (2011) examined the causes of bank failure in Nigeria using primary data and questionnaire in the analysis. Moreover, simple percentage was used in the analysis of data. The study revealed that capital inadequacy, lack of transparency and non-performing loans as the major causes of bank failure in Nigeria. The study recommends full disclosure of all financial transactions and separation of the post of the chairman from that of managing director for all the banks as the best approach in forestalling bank failure in Nigeria.

Ebiringa (2011) added the literature on the topic by investigating the benchmarking indices of distress in the Nigerian banking industry. The study used Altaman scale in predicting bank distress. The results indicated that Altman model is reliable in predicting bank distress. The study however, suggested that further study should be carried out in order to improve the validity of prediction of bank failure in the country.

Ademola, Olusegun and Kehinde (2013) examined how the activities of Nigeria Deposit Insurance Corporation forestall bank distress in Nigeria. The study used secondary data, correlation coefficient and t-test in the analysis of relationship among the variables. Study found that there is an increase in deposit mobilization as a result of increase in deposit guarantee. They further discovered the transmission of NDIC from the flat premium rate assessment system to differential assessment system. The study recommends the frequent review of deposit cover in consistent with the dynamic change of an economy.

\section{Methodology}

This paper used annual data spanning from 1986 to 2015 for the estimation. The data is obtained from Statistical Bulletin of the Central Bank of Nigeria (CBN). Moreover, the study adapts a model from the work of Nzotta and Okereke (2009) and Ohwofasa and Mayuku (2012) to determine the causes of bank distress in Nigeria. The variables included in the model are bank distress which is proxy financial deepening (FD), interest rate (IR), inflation rate (INF), exchange rate (EXR), non-performing loans (NPL) and liquidity ratio (LR). However, the rationale behind the use of financial deepening in place of bank distress is that, financial deepening is the ratio of money supply to economic growth. Implying that the more liquid money available in the economy the more opportunities in the economy to continue to grow and vice versa. It also represents the situation where by bank is free from financial repression (Nzotta and Okereke, 2009) and vice versa. The model is given as:

$$
\mathrm{FD}=f(\mathrm{EXR}, \mathrm{INF}, \mathrm{IR}, \mathrm{LR}, \mathrm{NPL})
$$

Econometric model is given as:

$$
F D_{t}=\beta_{o}+\beta_{1} E X R_{t}+\beta_{2} I N F_{t}+\beta_{3} I R_{t}+\beta_{4} L R_{t}+\beta_{5} N P L_{t}+\mu_{t}
$$

The study adopts Autoregressive Distributed Lag (ARDL) approach developed by Pesaran et al. (2001) to estimate equation (2). The choice of the ARDL is based on the following reasons: Firstly, the model can be applied irrespective of whether the series under investigation are stationary at $\mathrm{I}(0)$ or $\mathrm{I}(1)$ or mixture of both. Secondly, it provides robust and high quality result even if sample size is small or large. Finally, it takes into account the error correction model. The analysis of error correction and autoregressive lags fully covers both long-run and short-run relationships of the variable under study (Pesaran et al; 2001). Following the work of Pesaran et al(2001), the ARDL model of equation (2) is given as:

$$
\begin{aligned}
& \Delta F D_{t}=\beta_{o}+\sum_{i=1}^{m} \beta_{1} \Delta F D_{t-i}+\sum_{i=1}^{m} \beta_{2} \Delta E X R_{t-i}+\sum_{i=1}^{m} \beta_{3} \Delta I N F_{t-i}+\sum_{i=1}^{m} \beta_{4} \Delta I R_{t-i}+\sum_{i=1}^{m} \beta_{5} \Delta L R_{t-i} \\
& +\sum_{i=1}^{m} \beta_{6} \Delta N P L_{t-i}+\alpha_{1} F D_{t-1}+\alpha_{2} E X R_{t-1}+\alpha_{3} I N F_{t-1}+\alpha_{4} I R_{t-1}+\alpha_{5} L R_{t-1}+\alpha_{6} N P L_{t-1}+\mu_{t}(3)
\end{aligned}
$$

Although, the ARDL model consist of two parts, the first part of the equations with $\beta_{1}$ to $\beta_{6}$ stand for the short-run dynamics of the models, while the coefficients $\alpha_{1}$ to $\alpha_{6}$ represents the long-run relationship. The null hypothesis of the above model is defined as $\mathrm{H}_{0}: \alpha_{1=} \alpha_{2=} \alpha_{3=} \alpha_{4=} \alpha_{5=} \alpha_{6=0}$ which tell us that there is no cointegration (no existence of long run relationship) among the variables under estimation (Pesaran et al.2001).

We begin the estimation by conducting a bounds (ARDL) test for the null hypothesis of non-existence of long-run relationship. The calculated F-statistics is compared with the critical value as tabulated by Pesaran et al (2001). If F-statistics exceeds or supersedes the upper critical value, then the decision rule will be to reject the null hypothesis of no long-run relationship (no cointegration) irrespective of whether the underlying order of integration of the variables is zero or one i.e. $\mathrm{I}(0)$ or $\mathrm{I}(1)$, whereas if F-statistics falls below a lower critical value, then the null hypothesis cannot be rejected and if F-statistics falls within these two critical bounds, then the result is inconclusive(Pesaran et al, 2001).

The general error correction model of equation (3) is given as:

$$
\Delta F D_{t}=\beta_{0}+\sum_{i=1}^{m} \beta_{1} \Delta F D_{t-i}+\sum_{i=1}^{m} \beta_{2} \Delta E X R_{t-i}+\sum_{i=1}^{m} \beta_{3} \Delta I N F_{t-i}+\sum_{i=1}^{m} \beta_{4} \Delta I R_{t-i}+\beta_{5} L R_{t-i}+
$$


$\sum_{i=1}^{m} \beta_{6} \Delta N P L_{t-i}+\beta_{7} E C M_{t-i}+\mu_{t}$

Where ECM is the error correction representation of the equation

Furthermore, before estimating equation (3), the study conducted a unit root test through the use of Augmented Dickey-Fuller and Phillips-Perron.

\section{Empirical Results}

Although, ARDL does not require pre-testing of series variables, but the study decide to determine the order of integration of all the variables under estimation before conducting ARDL test. This is because ARDL does not handle any series that go beyond first difference (i.e. I(1)) order of integration. Table 1 shows the results of ADF and P-P unit root tests.

Table 1: Unit Root Test (Augmented Dickey-Fuller and Phillips-Perron)

\begin{tabular}{|c|c|c|c|c|}
\hline \multirow[t]{2}{*}{ Variables } & \multicolumn{2}{|c|}{ Augmented Dickey- Fuller } & \multicolumn{2}{|c|}{ Phillips-Perron } \\
\hline & Level & First Diff. & Level & First Diff. \\
\hline FD & & $-5.022256 * * *$ & & $-5.846360 * * *$ \\
\hline EXR & & $-5.003944 * * *$ & & $-5.003944 * * *$ \\
\hline INF & $-3.094193 * *$ & & $-3.163800 * *$ & \\
\hline IR & $-2.917643 *$ & & $-2.974795 * *$ & \\
\hline $\mathbf{L R}$ & $-2.812033^{*}$ & & $-2.918443^{*}$ & \\
\hline NPL & & $-6.67919 * * *$ & & $-7.192777 * * *$ \\
\hline
\end{tabular}

From Table 1, the results based on ADF and P-P tests show that financial deepening, exchange rate and non-performing loans were stationary at the first difference, while inflation, interest rate and liquidity ratio were stationary at level values. However, the nature of results obtained from the unit root tests led to the adaption of ARDL and the results from Bounds test of ARDL presented in table 2, reveals the presence of cointegration (long-run relationship) among the variables.

Table 2: ARDL Bounds Test

\begin{tabular}{|l|l|l|}
\hline Test Statistics & $\mathbf{3 . 1 9}$ \\
\hline F-Statistics & I(0) Bound & I(1) Bound \\
\hline Critical Value Bounds & $\mathbf{3 . 0 6}$ & $\mathbf{4 . 1 5}$ \\
\hline Significance & $\mathbf{2 . 3 9}$ & $\mathbf{3 . 3 8}$ \\
\hline $\mathbf{1 \%}$ & $\mathbf{2 . 0 8}$ & $\mathbf{3 . 0 0}$ \\
\hline $\mathbf{5 \%}$ & $\mathbf{1 0 \%}$ \\
\hline Source: Authors Computation From Eviews Output. \\
\hline
\end{tabular}

From Table 2, the F-calculated value (i.e. 3.19) shows that the null hypothesis of no long-run relationship can be rejected at $10 \%$ level of significance. This is because F-statistics is greater than the upper bound critical value of 3.00 and 2.08 for lower bound critical value. Furthermore, the ARDL long-run result presented in Table 3, indicates that exchange rate is positively associated with financial deepening (i.e. 0.130) and statistically significance at $1 \%$ level. Implying that a unit increase (decrease) in exchange rate will lead to a $13 \%$ increase (decrease) in financial deepening. This is inconsistent with our expectation, because exchange rate is one of the determinants of assessing the performance of an economy. A very strong exchange rate is a reflection of strong and viable financial sector of an economy. While on the other hand, a very weak currency is a reflection of a very vulnerable, distress and weak financial sector of an economy.

Inflation has negative and statistically insignificant impact on financial deepening. It means that a unit increase (decrease) in inflation will lead a $0.8 \%$ decrease (increase) in financial deepening. During the period of high inflationary pressure, consumers are unable to save, because the savings portions of their income are invaded by consumption as a result of unstable price. Furthermore, decreases in saving imply decrease in financial deepening, leading to unable for the bank to meet the costumers demand for cash (i.e. bank distress). The result also shows that interest rate is negatively related to financial deepening. A $1 \%$ increase (decrease) in interest rate will lead to about $39.8 \%$ decrease (increase) in financial deepening. High interest rate in the economy may reduce the ability of businessmen and companies to borrow from the bank in order to increase their investment. This reflects into reduction in bank's rate of return and output which affect the general price level. Savings and financial deepening further affected negatively due to high price level and the resulting effect is bank distress. Hence the result is statistically insignificant as shown by its p-value of 0.176 . 
Liquidity ratio has positive and statistically insignificant influence on financial deepening. This indicates that $1 \%$ rise in bank's liquidity ratio will lead to about $7.9 \%$ increase in liquid money available to the bank. Additionally, a unit reduction in bank's liquidity ratio may cause negative impact on financial deepening leading to failure for the bank to satisfy the costumers demand for money.

Finally, non-performing loans has positive and statistically significant influence on financial deepening in Nigeria. An increase (decrease) in non-performing loans will lead to increase (decrease) in financial deepening. This implies that a one percentage rise in non-performing loans will trigger about 36.6 percentage increase in financial deepening in Nigeria.Meaning that non-performing loans increases the bank capability to satisfy the needs of its customers. This is inline with finding of Elegbe (2013), and contradicts the theoretical idea that non-performing loans exert negative effect on financial deepening. However, Elegbe (2013) noted that market imperfection, previous banking crisis, inconsistencies in government policies and several banking reforms in Nigeria as the major factors behind this conflicting finding.

Table 4: Result of the Estimated Long-Run Coefficients of the ARDL

\begin{tabular}{|l|l|l|l|l|}
\hline \multicolumn{5}{|l|}{ Dependent Variable: FD } \\
\hline Variables & coefficients & std. Error & t-Statistics & Prob. \\
\hline EXR & $\mathbf{0 . 1 3 0}$ & $\mathbf{0 . 0 2 2}$ & $\mathbf{5 . 9 0 5}$ & $\mathbf{0 . 0 0 0}$ \\
\hline INF & $\mathbf{- 0 . 0 0 8}$ & $\mathbf{0 . 1 0 7}$ & $\mathbf{- 0 . 0 7 4}$ & $\mathbf{0 . 9 4 2}$ \\
\hline IR & $\mathbf{- 0 . 3 9 8}$ & $\mathbf{0 . 2 8 6}$ & $\mathbf{- 1 . 3 9 3}$ & $\mathbf{0 . 1 7 6}$ \\
\hline LR & $\mathbf{0 . 0 7 9}$ & $\mathbf{0 . 1 0 1}$ & $\mathbf{0 . 7 8 6}$ & $\mathbf{0 . 4 3 9}$ \\
\hline NPL & $\mathbf{0 . 3 6 6}$ & $\mathbf{0 . 1 0 2}$ & $\mathbf{3 . 5 8 6}$ & $\mathbf{0 . 0 0 2}$ \\
\hline $\mathbf{R}^{2}=\mathbf{0 . 4 9}$ Adjusted $\mathbf{R}^{2}=\mathbf{0 . 4 2}$ AIC $=\mathbf{6 . 1 7 2}$ SIC $=\mathbf{6 . 4 0 8} \mathbf{H Q N}=\mathbf{6 . 2 4 6}$ DW $=\mathbf{1 . 2 5 8}$ \\
\hline Source: Authors calculation from Eviews Output. \\
\hline
\end{tabular}

Furthermore, when the variables under estimation are cointegrated, then there must be error correction model (ECM) that expresses the short-run nexus among the variables. The logic behind this ECM is that, it describes the speed of adjustment from the short-run to the long-run equilibrium in the economy in case of any distortion. The ECM result is presented in Table 4 and it that ECM has correct sign (i.e. -0.39) and statistically significant at $10 \%$ level. This implies that about $39 \%$ of disequilibrium is corrected on annual basis in the presence of any unwanted happening in the economy. This is also showing that in the presence of any distortion in the economy, it takes less than three years (i.e. two years and six month) for the equilibrium to be reestablished.

Table 4: Error Correction Estimate of the ARDL Model

\begin{tabular}{|c|c|c|c|c|}
\hline \multicolumn{5}{|c|}{ Dependent Variable: $\square$ FD } \\
\hline Variable & Coefficients & std. Error & t-Statistics & Prob. \\
\hline c & 0.8815 & 0.8623 & 1.0222 & 0.3195 \\
\hline$\square$ EXR(-1) & -0.1203 & 0.0562 & -2.1395 & 0.0456 \\
\hline$\square$ INF(-1) & -0.0049 & 0.0652 & -0.0751 & 0.9409 \\
\hline$\square$ IR(-1) & $\mathbf{0 . 3 5 8 3}$ & 0.2189 & 1.6361 & 0.1183 \\
\hline$\square$ LR(-1) & 0.0911 & 0.1062 & 0.8582 & 0.4015 \\
\hline$\square$ NPL(-1) & -0.1166 & 0.1266 & -0.9208 & 0.3687 \\
\hline ECM(-1) & -0.3929 & 0.2194 & -1.7911 & 0.0892 \\
\hline \multicolumn{5}{|c|}{$\begin{array}{l}R^{2}=0.45 \text { Adjusted } \mathrm{R}^{2}=0.24 \text { AIC }=5.831 \text { SIC }=6.215 \mathrm{HQC}=5.945 \text { F-Statistics }=2.19 \\
\text { Prob }(\text { F-Stat })=0.08 \mathrm{DW}=1.790\end{array}$} \\
\hline Source: $A$ & lation from & itput. & & \\
\hline
\end{tabular}

To ensure the stability of the equation and the estimated parameters under estimation, the study employed the most frequently used techniques of CUSUM and CUSUMSQ tests. The results are presented in figure 1 and 2 respectively. The equation and parameters are said to be stable, if the sum of recursive errors fall strongly within the two critical lines.The results from figure 1 shows that, parameters of the estimated equation were stable because the recursive errors fall between the two critical lines of the CUSUM test. However, the CUSUMSQ result in figure 2 crossed the two critical lines indicating instability of the parameters. This instability is associated with 2004-2005 banking reforms in Nigeria and 2008-2009 global economic crisis. 


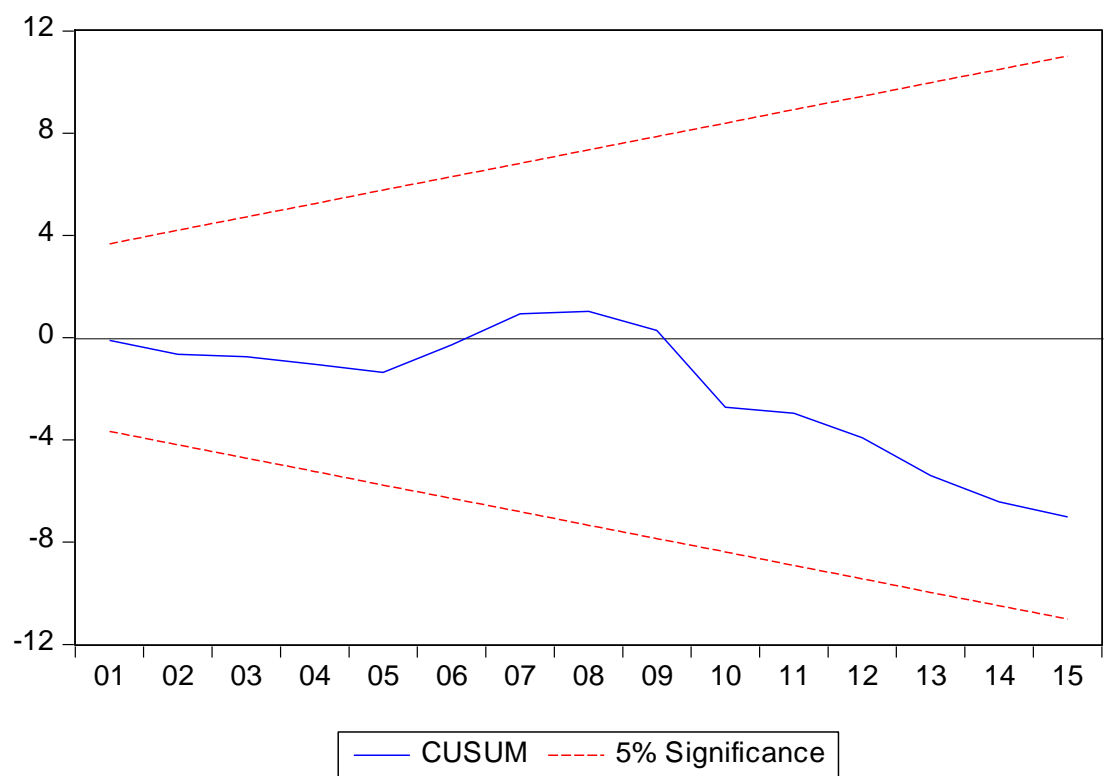

Figure 1: Cumulative Sum of Recursive Residual Test.

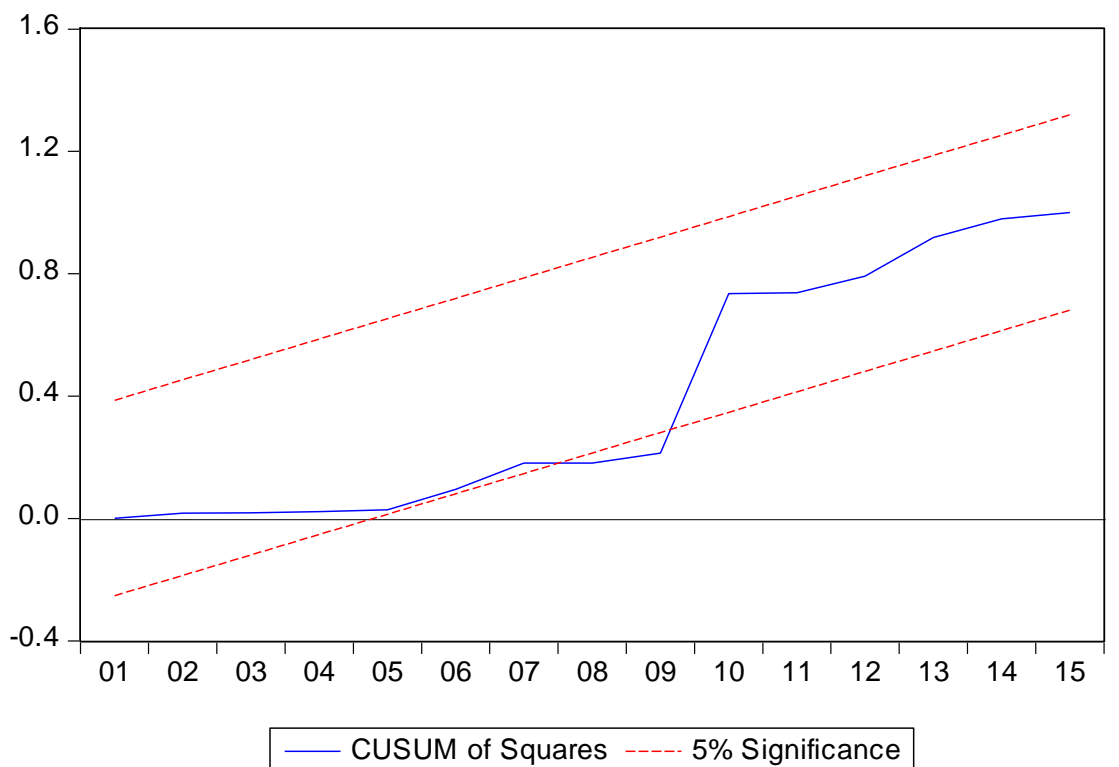

Figure 2: Cumulative Sum of Square of Recursive Residual Test

\section{Conclusion And Recommendations}

The quest to find out the real causes of bank distress has captured the interest of many stockholders in the field of banking and finance. Some believed that bank distress is rooted by inadequate capital, high level of non-performing loans, lack of transparency, illiquidity and weak management among others. While others believed that distress in the banking sector is associated with instability in macroeconomic variables such as exchange rate, inflation, interest rate, economic growth, unemployment, investment, savings and the rests. To add value to the existing findings, this study examines the causes of bank distress in Nigeria using annual data from 1986 to 2015 with the aid of ARLD and revealed that exchange rate and non-performing loans have positive and statistical significant effect on bank distress, while inflation and interest rate have negative and statistical insignificant effect on bank distress. The study further found that liquidity ratio exerts positive and statistically insignificant influence on bank distress. In consistent with the findings, the study recommends the followings: firstly, there should be proactive measures by the banks such as loan surveillance and monitoring and also to guarantee effective control of non-performing loans, banks should ensure that loans satisfy the requirements of banking policy. Finally, the Central Bank of Nigeria should make sure that deposit money banks are operating in line with the banking policy guide lines and any bank that violate or bridge the policy should be call to order or penalized.The government should strengthen the mechanisms that will create favorable and sustainable macroeconomic stability in the economy; 


\section{References}

[1]. Abiola A.B., Felica O.O. and Folasade B.A. (nd) "Predicting Bank Failure in Nigeria Using Survival Analysis Approach.

[2]. Ademola O.G.J., Olusegun O. and Kehinde O. (2013) "Bank Distress in Nigeria and the Nigerian Deposit Insurance Corporation Intervention", Global Journal of Management, Business and Finance Research, Vol. 13, No. 8, ISSN: 2249-4588.

[3]. Adeyemi B. (2011)"Bank Failure in Nigeria: A Consequence of Capital Inadequacy, Lack of Transparency and Non-performing Loans", Banks and Bank Systems, Vol. 6, No. 1.

[4]. Alashi S.O. (2002) "Banking Crisis: Causes, Early Warning Signals and Resolution in Central Bank of Nigeria", Conference Proceedings on Enhancing Financial Sector Soundness in Nigeria, Abuja, CBN Pp. 126-153

[5]. Central Bank of Nigeria (2011) Annual Report.

[6]. Ebiring O.T (2011) "Benchmarking Incidence of Bank Distress in the Nigerian Banking Industry on Altiman Scale", Serbian Journal of Management, 6(2), 221-230, Available at: www.sjn06.com.

[7]. Egbo O. P. (2012) "Universal Basis of Bank Failure- the Nigeria Case", Developing Country Studies, Vol. 2., No. 10, ISSN: 2224607X (paper), ISSN: 2225-0565 (online) available at: www.iiste.org.

[8]. Elegbe A.(2013) "Bank Failure and Economic Development in Nigeria: An Empirical Approach", British Journal Economics, Finance and Management Sciences, Vol. 8, No. 1, ISSN: 2048-125X.

[9]. Musa N.Y, Musa J. and Abdulsalam N.K., (2012)" Bank Recapitalization in Nigeria: Resuscitating Liquidity or Forestalling Distress", International Journal of Business and Social Sciences, Vol. 3, No. 10.

[10]. Nnah U.J.N. (2012) "Poor Credit Risk Management and Bank Failure in Nigeria", Article in SSRN Electronic Journal, available at: http://www.researchgate.net/publication/255857560.

[11]. Nzotta, S.M and Okereke E.J. (2009) "Financial Deepening and Economic Development in Nigeria: An Empirical Investigation", African Journal of Accounting, Economics, $\quad$ Finance and Banking Research, Vol. 5, No. 5.

[12]. Ogunbunka U.M. (2003) "Walking Ahead of Bank Distress. The Secretes of Safeguarding your Money in Banks", Lagos Rhema Enterprises, Pp. 19-26.

[13]. Ogundina A.(1999) "The Nigerian Banking and Financial Environment, Ibadan Immaculate Press, Pp. 138-151.

[14]. Ohwofasa B.O. and Mayuku J.G.(20120 "Determinants of Bank Distress and Effect on NigerianEconomy, 1986-2010: An Empirical Analysis", European Journal of Humanities and Social Sciences, Vol. 17, No. 1, ISSN: 2220-9425.

[15]. Pesaran H., Smith R. and Shin Y. (2001) "Bound Testing Approach to the Analysis of level relationships", Journal of Applied Econometrics, 16(3), 289-326.

[16]. Sanusi L.S.(2010) "The Nigerian Banking Industry: What Went Wrong and the Way Forward", A paper Presented at the convocation Square, Bayero University Kano.

[17]. Umoh P.N. (1999) “A Decade of Deposit Insurance in Nigeria: Issues and Challenges, Lagos NDIC. 